\title{
Süt ve Süt Ürünlerinin Ambalajlanmasında Yenilikçi ve Doğal Yaklaşımlar; Esansiyel Yağların Kullanıldığı Polimerik Aktif Ambalaj Çözümü
}

\section{Betül ERTEKIN ${ }^{* 1}$ [D}

\author{
${ }^{1}$ Aydın Adnan Menderes Üniversitesi Ziraat Fakültesi Süt Teknolojisi Bölümü, Aydın
}

Öz: Ambalajlı süt ve süt ürünlerinde kimyasal katkı maddelerinin bulunduğu yönündeki yanlış tüketici algısına rağmen ambalajlama sektörü, içerisindeki ürünün kalite ve güvenilirliğini depolama süresince koruyan doğal yöntemler geliştirmeye devam etmektedir. Aktif ambalajlama, gıda içerisine herhangi bir katkı maddesi katılmaksızın, polimerik ambalaj üzerinden korumanın sağlandığı yenilikçi yaklaşımlardan biridir. Aktifleştirme ajanı olarak esansiyel yağların kullanımı ise, koruyucu ve lezzet verici özellikleriyle yüzyıllardır kullandığımız bitki ve baharatların, ambalaja dahil edildiği son derece doğal ve güvenilir bir çözüm ortaya koymaktadır.

Bu çalışmada, aktif polimerik ambalajlama teknolojisinde kullanılan esansiyel yağlar üzerinde durulacaktır. Mikroorganizma üremesine elverişli ve aynı zamanda kompleks yapısı itibariyle de bozulma potansiyeli yüksek bir gıda grubu olan süt ve süt ürünlerinin ambalajlanmasında kullanımları değerlendirilmiştir.

Anahtar Kelimeler: aktif ambalaj, polimerik ambalaj, uçucu yağ

Innovative and Natural Approaches in Packaging of Milk and Dairy Products; Polymeric Active Packaging Solution Using Essential Oils

Abstract: Despite the wrong consumer perception that there are chemical additives in packaged milk and dairy products, the packaging sector continues to develop natural methods that maintain the quality and reliability of the product during storage. Active packaging is one of the innovative approaches in which protection is provided through activating agents without the addition of any additives into food. The use of essential oils as an activating agent provides a very natural and reliable solution in which the herbs and spices that we have been using their protective and flavouring properties for centuries have been included in the package.

In this study, the essential oils in active polymeric packaging technology will be emphasized. Their use in the packaging of milk and dairy products which are possible for microorganism growth and at the same time having high deterioration potential due to their complex structure, was evaluated.

Keywords: active packaging, polymeric package, volatile oil

\section{GiRiş}

Süt ve süt ürünlerinin tüketiminin artırılması, toplum sağlığı açısından önemli olduğu kadar süt ve süt ürünleri üreticileri için de önem arz eden bir konudur. Ne var ki sağlıklı ve doğal ürünleri tercih etmek isteyen tüketicilerin, "bu ürünlerin muhafazası için ancak ve ancak ürüne kimyasal katkı maddeleri eklenmesi gibi yöntemlerin uygulandı̆̆ı" yönünde yanlış inanışlara maruz kalabildiği de gerçektir. Günümüzde, ısıl işlemler ve aseptik ambalajlama yöntemleri gibi daha pek çok uygulama ile süt içerisine herhangi bir katkı maddesi katılmaksızın gıda kalitesi ve güvenilirliği sağlanabilmektedir. Bunlara ek olarak aktif ambalajlama teknolojisi ile de, ürüne bulaşmış zararlıların inhibe edilmesi, ürün içerisinde sonradan oluşması muhtemel bozucu etkenlerin ortamdan uzaklaştırılması ve/veya hava, nem, çeşitli gazlar gibi faktörlere bağı bozulmaların önüne geçilmesi mümkün olabilmektedir.

Aktif ambalajlar, içerisindeki ürünün kalite ve tazeliğini korumak amacıyla, ambalaja ilave edilmiş fonksiyonel bileşenlere sahip malzemelerden oluşur. Bu malzemeler, gıda maddesinin bulunduğu ambalaj ortamına salım yapabilen ya da o ortamda gıda tarafından salınabilecek bileşenleri tutabilen aktif ajanlar içerir. "Salıcı aktif ajanlar", örneğin $\mathrm{CO}_{2}$ veya etanolün ambalaj ortamına salınmasını sağlayarak, "emici aktif ajanlar" da, örneğin ambalaj içerisindeki su buharı, oksijen veya etileni emerek koruma özelliği sağlar ve gıdanın raf ömrünü uzatır (Dey ve Neogi, 2019, Vilela ve ark., 2018).

Antimikrobiyal aktif ambalajlarda ise ulaşılmak istenen hedef, ambalaj içerisindeki mikroorganizmaların inhibe edilmesidir. Antimikrobiyal aktif ambalajda hem salıcı hem de emici aktif ajanların kullanımı mümkün olabilmektedir (Vilela ve ark., 2018). Burada amaçlanan, gıda ve ambalaj malzemesinde bulunan mikroorganizma gelişiminin azaltılması, geciktirilmesi veya engellenmesidir.

Süt ve süt ürünleri yapısı gereği kolaylıkla bozulmaya açık bir gıda gurubudur. Bu ürünlerin ambalajlanarak satışı, hem gıda güvenilirliğini hem de gıda kalitesini sağlamada önemli bir rol üstlenmektedir. Süt grubunun üretiminde ilk akla gelen bozulma nedeni, patojen mikroorganizma üremesidir. Üretimde uygulanan ısıl işlemle büyük ölçüde ortadan kaldırılan mikroorganizmalar, genellikle alet ve ekipman temizliğine bağlı olarak tekrar bulaşabilmekte veya üretim

Sorumlu Yazar: betul.ertekin@adu.edu.tr

Geliş Tarihi: 31 Temmuz 2019

Kabul Tarihi: 29 Nisan 2020 
prosesi sonrasında elle işlem görmeye bağlı olarak gelişebilmektedir (Metin, 2012). Ayrıca havada bulunması muhtemel maya ve küf sporları ile kontaminasyon neticesinde gelişen mikrobiyolojik bozulmalara da sıklıkla rastlanır (Kılıç, 2010). Bir diğer konu da sütün kimyasal bileşiminde onu diğer gıda maddelerine oranla öne geçirecek zenginlikte lipid ve lipid türevlerinin bulunmasıdır. $\mathrm{Bu}$ nedenle lipid oksidasyonuna da dikkat edilmelidir. Bu durumda süt ve süt ürünlerinin aktif ambalajlanmasında kullanılabilecek ambalaj türünün, hem antimikrobiyal özellikler göstermesi, hem de ürünün türüne göre antioksidan özellikte olması önemlidir.

Esansiyel yağlar, antimikrobiyal ve antioksidan özellikleriyle dikkat çeken doğal uçucu bileşiklerin bir karışımıdır. Doğada bulunan bazı bitkiler tarafından sekonder metabolitler olarak üretilirler. Bu bitkisel özlerin geneli Gıda ve îlaç İdaresi (FDA) tarafından gıda katkı maddesi olarak kullanımda güvenli kategorisinde tanımlanmaktadır (Anonim, 2016). Ancak gıda koruyucu olarak etkili antimikrobiyal dozları kabul edilebilir organoleptik seviyenin üstüne çıkabileceğinden kullanımları genellikle sınırlıdır (Viuda-Martos ve ark., 2008). Gıda ambalajlarına dahil edilerek kullanımlarında ise, etken maddenin ürüne difüzyonu sınırlandırılmış olacağından gıdaların tat ve aromasında rahatsız edici bir değişiklik yapılmaksızın uygulanması sağlanabilmektedir (Ju ve ark., 2019).

Hazırlanan bu derleme çalışmasında, çeşitli bitki ve baharatların özünde bulunan esansiyel yağların ambalajlama teknolojisinde kullanımları üzerine yoğunlaşılmış, süt ve süt ürünlerinin ambalajlanmasında uygulamalarına yönelik literatür örnekleri derlenmiştir. Aktif bileşen olarak esansiyel yağların kullanıldığı ambalajlar, ürünü doğal yollarla koruyarak tüketicinin mutfağına kadar sağııklı ve taze olarak getirmeye adaydır.

\section{Esansiyel Yağlar}

Esansiyel, aromatik ya da bir başka deyişle uçucu bileşikler, genellikle sıcak iklimlerde yetişen bazı bitkilerin yaprak, tohum, çiçek, tomurcuk ve soğanlarından elde edilen, suda

Çizelge 1. Bazı bitki ve baharatların esansiyel yağlarında bulunan başlıca bileşenler

\begin{tabular}{llll}
\hline Bitki & Latince İsmi & Esansiyel Yağın Başlıca Bileşenleri & Kaynak \\
\hline Adaçayı & Salvia officinalis & Borneol, Kafur, Karyofillen, Sineol & Ghorbani ve Esmaeilizadeh, 2017 \\
Biberiye & Rosmarinus officinalis & Sineol, Kafur, $\alpha$-pinen & Takayama ve ark., 2016 \\
Fesleğen & Ocimum basilicum & Linalool, Eugenol, Metil-eugenol & Pandey ve ark., 2014 \\
Kekik & Thymus vulgaris & Timol, Kamfen, Kariyofilen, Humulen & Al-Asmari ve ark., 2017 \\
Kimyon & Fructus cumini & Carvon ve limonen & Mahboubi, 2018 \\
Rezene & Foeniculum vulgare & Trans-anethol, Fenchone, Estragol & Rather ve ark., 2016 \\
Karanfil & Dianthus caryophyllus $L$. & Eugenol, $\beta$-kariyofilen, $\alpha$-humulen & Wynn ve Fougère, 2007 \\
Tarçın & Cinnamomum verum & Cinnamaldehit & Hamidpour ve ark., 2015 \\
Karabiber & Piper nigrum & $\beta$-pinen, Limonen, Mirsen, Linalol & Tchatchouang ve ark., 2017 \\
Nane & Mentha xiperita & Menthol, Menthone, Mentil asetat & Desam ve ark., 2017 \\
\hline
\end{tabular}

çözünmeyip organik çözücülerde çözünebilen ve bu özellikleri ile de yağları anımsatan maddelerdir (Tiwari ve ark., 2009). Bu bitkilere kendine has koku ve aromayı veren esansiyel bileşenleri arasında başlıca, seskiterpenler, monoterpenler, aldehitler, alkoller, esterler ve ketonlar içeren çeşitli uçucu kompleks karışımlar bulunmaktadır (Tohidi ve ark., 2019). Bu bileşikler aynı zamanda antimikrobiyal ve antioksidatif etkiden de sorumludur. Çizelge 1'de bazı bitki ve baharatların esansiyel yağlarında rastlanan başlıca bileşenlere örnekler gösterilmektedir. Bununla birlikte herhangi bir bitkiye ait esansiyel bileşenlerin yüzde oranlarının; bitki türüne, hasat mevsimine, bileşenleri damıtma yöntemine, bitkinin yetiştiği coğrafya ve çevresel faktörlere göre değişiklik gösterebileceği göz önünde bulundurulmalıdır (RibeiroSantos ve ark., 2017, Küçük, ve ark., 2018, Katar ve ark., 2018).

Esansiyel yağların geleneksel olarak aroma ve lezzet verici etkileriyle gıda maddelerinde kullanımlarının yanı sıra en sık rastlanan kullanım amacı, antimikrobiyal etkinlikleridir. Bu bileşiklerin mikroorganizmalara etki mekanizması hakkında çeşitli görüşler mevcuttur. Genel olarak, yapılarında bulunan fenolik bileşiklerin hücre duvarının protein yapısına nüfuz ettiği, protein denatürasyonuna ve hücre zarının tahrip olmasına neden olduğu düşünülmektedir (Ju ve ark., 2019). Böylece, çekirdek de dahil olmak üzere hücresel bileşenlerin çalışması durmaktadır (Vilela ve ark., 2016). Bu konuda yapılmış bazı çalışmalar, genellikle gram pozitif bakterilerin esansiyel yağ bileşiklerine gram negatif bakterilerden daha duyarlı olduğunu söylemektedir (Fisher ve Phillips, 2008). Bununla birlikte, her iki tip üzerinde de aynı etkiyi gösterdiklerine dair çalışmalar da vardır (Ghadetaj, 2018). Bu çalışmalar arasındaki farklılıkların nedeninin uçucu yağların aktivitesinin; kompozisyon, fonksiyonel gruplar ve bileşenler arasındaki sinerjistik etkileşimlerle ilgili olduğu düşünülmektedir (Dorman ve Deans 2000). 
Esansiyel yağların, antioksidatif özellikleri ise gıda korumada faydalanılan ikinci temel özellikleridir. Kimyasal olarak, bileşimlerinde bulunan fonksiyonel grupların antioksidatif etkiden sorumlu oldukları anlaşılabilir. Bu yönüyle besinlerin bozulmasına sebep olan yükseltgenme reaksiyonlarını durdurdukları bilinmektedir (Atares ve Chiralt, 2016).

Esansiyel yağların çok çeşitli mikroorganizmalara karşı etkili olması ve aynı zamanda güçlü antioksidan etkileri dolayısıyla tek başına veya karışım halinde gıda katkı maddelerinde kullanımları mümkündür. Aynı zamanda sentetik katkı maddelerinin insan sağlığı üzerine olası yan etkileri ve tüketicilerin doğal ürünlere olan yönelimleri de göz önünde bulundurulduğunda, gıdalarda kullanımlarına yönelik bilimsel çalışmalar giderek artış göstermektedir.

Esansiyel Yağların Polimerik Ambalaj Malzemelerinde Kullanımı

Esansiyel yağların veya içerdikleri bileşenlerin gıda ambalajlarında kullanımları üzerine yapılan ilk çalışmalara doksanlı yılların ortalarında rastlanmaktadır (Comer v.d. 1995, Suzuki ve Yagishita, 1997, Minagawa, 1997 ). Ilk patent çalışmalarında, selülöz türevleriyle enkapsüle edilen esansiyel yağlara (Comer ve ark., 1995) ve esansiyel yağlarla kompozit oluşturan termoplastiklere (Nakahara ve ark, 1995, Minagawa, 1997) yer verilmiştir.

Günümüze gelindiğinde, esansiyel yağların gıda ambalajlarında kullanımları hakkında çok sayıda çalışma olduğu dikkat çekmektedir. Bu çalışmalar 2010'lu yıllardan itibaren hız kazanmıştır. Son yıllarda yapılan çalışmalar değerlendirildiğinde, esansiyel yağların aktif ambalajlarda kullanımında 4 farklı yol göze çarpmaktadır. Bu yöntemler Şekil 1'de şematize edilmiştir.

\begin{tabular}{|c|c|}
\hline Polimerik Film ${ }^{\circ} \circ \circ \circ \circ$ & Polimerik Film \\
\hline Gıda Ortamı & Gida Ortami \\
\hline Polimerik Film & 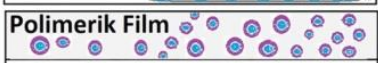 \\
\hline Gıda Ortamı & Gıda Ortamı \\
\hline
\end{tabular}

Şekil 1. Aktif ambalajlarda esansiyel yağların kullanım şekilleri a) Doğrudan ambalaj malzemesi içine karıştırma b) Küçük bir kese içerisinde ambalaj içine bırakılma, c) Ambalaj malzemesi üzerine adsorbe edilme, d) Mikro veya nanokapsüllenerek ambalaja dahil edilme

Doğrudan ambalaj malzemesi içerisine karıştırma: Bu yöntem teknolojik açıdan nispeten kolay olduğu için yaygın olarak incelenmiştir (Kuorwel ve ark., 2013; Huang ve ark., 2019). Ancak bu yöntemde esansiyel yağ ilavesinin polimer matrisinin mikroyapısını ve fizikokimyasal özelliklerini etkilemesi söz konusu olduğundan ambalaj malzemesinin mekanik özelliklerine ve esansiyel yağın elde edilen filmden salım oranlarına dikkat edilmesi gerekmektedir (Ju ve ark., 2019). Çeşitli esansiyel yağlar ve polimer matrisleri ile yapılmış olan çok sayıda çalışmada çekme, bariyer ve optik gibi fiziksel özelliklerin, polimer-esansiyel yağ etkileşimlerine bağlı olarak değişiklik gösterdiği belirtilmiştir (Atares ve Chirald, 2016). Çok sayıda değişkene bağı olmakla birlikte genel olarak esansiyel yağ ilavesiyle film yapısı zayıflamakta, su bariyer özelliği iyileşmekte, şeffaflık azalmakta, oksijen bariyer özelliği artmaktadır. Burada kaydedilmesi gereken önemli nokta, kitosan gibi doğal polimerlerin, zaten iyileştirilmesi gereken işlenebilirlik ve geçirgenlik özelliklerinin esansiyel yağların ilavesiyle olumlu yönte etkilendiğidir (Abdollahi ve ark., 2012).

Küçük bir kese içerisinde ambalaj içine bırakılma: Bir diğer yöntem olan aktif ambalajın bir kese içerisinde ambalaj içerisine bırakıldığı durumda, esansiyel bileşen buharının ürünün bulunduğu ortama salınması söz konusudur. Çeşitli çalışmalarda, esansiyel yağların gıda bozucu patojenlere karşı gaz fazında uygulandıklarında, sıvı formdakinden daha etkili oldukları ve aynı zamanda da daha az organoleptik kusura sebep oldukları belirtilmiştir (Tyagi ve Malik, 2011). Esansiyel yağlarla aktifleştirilen keseler, özellikle düzensiz şekle ve gözenekli yüzeye sahip gıda ürünlerinin muhafazasında faydalı olmaktadır (Jin ve ark., 2018). Ancak bu yöntemde, kesenin zarar görmesi veya tüketiciler tarafından yanlış kullanılabileceği riskleri mevcuttur.

Ambalaj malzemesi üzerine kaplama veya adsorbe edilme: Esansiyel yağların aktif ambalajlamada kullanımında bir diğer yöntem, film yüzeyine adsorblanması veya kaplanması (immobilizasyon) şeklindedir. Yöntemin uygulanmasında, elektrospinleme (Wen ve ark., 2016), veya plasma polimerizasyon teknikleri (Lin ve ark., 2019) gibi yöntemler kullanılmaktadır. Bu yöntemle, aktif bileşenin kaplanması ekstrüzyon veya film dökme işleminden sonra gerçekleştirilebileceğinden dolayı aktif bileşen kaybının önlenmesi açısından daha uygun olabilir. Ayrıca polimer içerisine doğrudan karıştırma yönteminde olduğu gibi mekanik özelliklerde değişiklik olmaksızın aktifleştirme mümkündür (Ju ve ark., 2019). Bununla birlikte hava ve ışık geçirgenliği gibi bariyer özelliklerini etkileyebildiği de belirtilmektedir (Ju ve ark., 2019).

Mikro veya nanokapsüllenerek ambalaja dahil edilme: Mikrokapsülleme, aktif maddelerin mikro veya nano boyutta kapsül veya küreler oluşturacak şekilde uygun polimer ile kaplandığı bir işlemdir. Bu yöntemle, uçucu bileşenlerin kontrollü olarak salımına olanak sağlanabilmektedir. Böylece esansiyel yağların hoş olmayan lezzet ve aromasını gizlemek ve sistemi stabilize etmek mümkün olmaktadır (Ju ve ark., 2019). Aynı zamanda ışık ve ısıdan etkilenebilen bu bileşiklerin korunması için de uygun bir ortam sağlanabilmektedir (Froiio ve ark., 2019). Literatürde çeşitli amaçlarla kullanılan mikro ve nanokapsüllerin büyüklüğünün $1 \mathrm{~nm}$ ile $1000 \mu \mathrm{m}$ arasında değişebildiği, mikron boyutlu kapsüllerde esansiyel yağların antimikrobiyal aktivitesinin önemli ölçüde arttığı, nano- 
kapsüllemede ise esansiyel yağ salımının daha uzun süre ve etkin bir şekilde sağlandığı belirtilmektedir (Ju ve ark., 2019).

Gıda ambalajlamada esasiyel yağ içeren kapsüllerin incelendiği çok sayıda çalışma mevcuttur. Örnek olarak, Cheng ve ark. (2019) yapmış oldukları çalışmada, carvacrol esansiyel bileşiğini, $\beta$-siklodekstrin ile enkapsülleyerek, sodyum aljinal matrisi içerisine dağıtmışlar ve elde edilen biyokompozit filmin antifungal aktivitesini kanıtlamışlardır. Talón ve ark. (2019), farklı kapsülleme malzemeleri kullanarak öjenol esansiyel bileşiğini enkapsüle etmiş, nişasta filmleri ile biyokompozit hazırlayarak etkinliğini değerlendirmişlerdir. Yapılan çalışmada oleik asit varlığının, film hazırlanması sırasında olası esansiyel yağ kayıplarını önlediğini ve enkapsüllemenin öjenol salımını dengede tuttuğunu rapor etmişlerdir. Bir başka çalışmada, portakal suyundaki E-coli bakteriyel aktivitesini değerlendirmek üzere, bergamot ve portakal esansiyel yağları, katyonik polimetil metakrilat ile kapsüllenerek kullanılmış, ilginç bir şekilde esansiyel yağ bulundurmayan mikrokapsüllerin, bulunduranlar kadar olmasa da antibakteriyel etki gösterdikleri, bu durumun polimerin katyonik karakterine bağlı olduğu kaydedilmiştir (Froiio ve ark., 2019).

\section{Süt ve Süt Ürünlerine Yönelik Çalışmalar}

Litertürde, çeşitli gıdalara doğrudan koruyucu katılması yerine, esansiyel yağlar ile aktifleştirilen ambalajlar vasıtasıyla mikrobiyal kontaminasyonun önüne geçildiğini rapor eden sayısız çalışma bulunmaktadır. Ancak bunlar arasından süt ve süt ürünlerine odaklanılan çalışmalara son birkaç yılda rastlamaktayız. Ayrıca bu araştırmaların genelinde peynir türlerinin ambalajlanması üzerine çalışıldığı da dikkat çekmektedir.

Yapılan bir çalışmada, sorbik asit, benzoik asit, biberiye, kurkumin ve askorbik asit gibi çeşitli bileşenlerin, peynir ambalajlarında aktifleştirme ajanı olarak kullanımları değerlendirilmiştir (O' Callaghan ve Kerry, 2014). Bu çalışmada, süzme peyniri ve Emmental peyniri ambalajlarında kullanılan biberiye esansiyel yağı ve Kitosanın, peynir mikroflorası üzerine antibakteriyel aktiflikleri, hem tek başına ve hem de ikili kombinasyon halinde, diğer antimikrobiyallere oranla oldukça üstün bulunmuştur.

Bir başka çalışmada pembe biberden ekstrakte edilen esansiyel yağın, selüloz asetat filmlerinde aktif ajan olarak kullanımı denenmiştir (Dannenberg ve ark., 2016). Elde edilen film, dilimlenmiş mozzerella peynirinin ambalajlanmasında kullanılmış ve hem Gram pozitif, hem de Gram negatif bakteriler üzerinde etkili olduğu sonucuna varılmıştır. Bu çalışmada ayrıca esansiyel yağın peynir üzerine migrasyonu da incelenmiştir.

Bir diğer çalışmada, nişasta filmi, karanfil yaprağı esansiyel yağı ile aktifleştirilerek Queso Blanco peynirinin ambalajlanmasında kullanılmıştır (Yang ve ark., 2017). Bu çalışmada elde edilen aktif ambalajın L. monocytogenes'e karşı etkili olduğu kanıtlanmıştır. Ayrıca fiziksel olarak, şeffaf ve UV ışığına karşı bariyer özellik gösteren filmler elde edilmiştir. Aynı zamanda lipid oksidasyonuna karşı antioksidan aktivite gösterdiği de rapor edilmiştir.

Doğal antimikrobiyel olarak esansiyel yağların kullanıldığı bu çalışmaların pek çoğunda biyopolimerlerle hazırlanan ambalajlar kullanılmakta olduğu görülmektedir. Bu durumun en önemli sebebi, hazırlanan ambalajın gıda ürünü ile temas edecek olması nedeniyle karbonhidrat veya protein yapıda doğal polimerlerden temin edilmesinin tüketici açısından tercih sebebi olmasıdır (Kim ve ark., 2017). Doğada birikme yapmayan, çevre dostu ambalajlara olan ilginin artması da bu konuda etkilidir. Aynı zamanda, esansiyel yağların, mekanik ve bariyer özellikleri açısından geliştirilme ihtiyacı bulunan biyobozunur polimerlere olumlu katkı sağlaması da bu doğrultudaki araştırmalara kapı aralamaktadır.

Doğal polmerlerin yanı sıra sentetik polimerlerin kullanıldığı araştırmalar da mevcuttur. Bir çalışmada, Polipropilen (PP) ve Polietilen tereftalat (PET) filmlere aktif bileşen olarak kekik yağı ve/veya etil lauroil arjinat (LAE) katılarak değerlendirilmiştir (Otero ve ark., 2014). Çiğ sütten hazırlanarak olgunlaştırılan koyun peyniri ile denenen bu filmlerden sadece $\geq 6 \%$ LAE-PET ikilisinin Escherichia coli 0157:H7 suşuna karşı etkili olduğu bildirilmiştir. Çeşitli katılma oranlarının denendiği bu çalışmada esansiyel yağpolimer aktif ambalajlarında başarılı sonuç alınamamıştır.

Bir çalışmada, depolama esnasında erken maya ve küf gelişiminin gözlendiği bilinen Queso Blanco Peyniri'nde aktif yenilebilir film kaplama yöntemi denenmiştir (Gurdian ve ark., 2017). Çalışmada kullanılan peynir, işlevselliğinin artırılması amacıyla omega-3 çoklu doymamış yağ asitleri içeren keten tohumu yağı ile de zenginleştirildiği için oksidasyona duyarlı bir üründür. Bu durumda, hem antioksidan, hem de antimikrobiyal özellikleri ile bilinen kekik yağı kullanılarak ambalajlanması düşünülmüştür. Peynir altı suyu protein izolatı ile hazırlanan yenilebilir filmin, kekik yağı ile aktifleştirildiğinde, bu üründeki lipit oksidasyonunu önemli ölçüde sınırladığı, ayrıca maya ve küf büyümesini engellediği rapor edilmiştir. Benzer bir çalışma, Pimpinella saxifraga esansiyel yağı kullanılarak Ksouda ve ark. tarafından 2019'da gerçekleştirilmiş, uyumlu sonuçlar elde edilmiştir. Aynı zamanda duyusal analiz neticesinde tüketici tarafından takdir edildiği de vurgulanmıştır.

Peynirin aktif ambalajlanmasında daha yenilikçi çalışmalara örnek olarak nanoteknolojinin uygulandığı araştırmalar da mevcuttur. Bunlardan birinde Tatlısu ve ark. (2019), PVA/Peyniraltı suyu proteini polimer kompozit matrisinde timol esansiyel yağını elektrospinleme tekniği kullanarak nanofiber yapıda üretmişlerdir. Elde edilen filmin kaşar 
peynirinde küf büyümesi üzerine etkisini incelemişlerdir. Bir başka çalışmada ise polimer matrisi içerisinde çinko oksit, gümüş-bakır nanotanecikleri ile, tarçın, sarımsak ve karanfil esansiyel yağlarının sinerjistik etkisi değerlendirilmiştir (Ahmed ve ark., 2016). Çalışmada, L. monocytogenes ve S. typhimurium büyümesini inhibe eden olumlu sonuçlar kaydedilmiştir.

\section{SONUÇ}

Antimikrobiyal ve antioksidan aktif ambalajlar, doğal aktifleştirme ajanlarının kullanımına olanak sağlayan yenilikçi ambalaj çözümlerindendir. Esansiyel yağlar, antimikrobiyal ve antioksidan özellikleri kanıtlanmış ve güvenli olarak sınıflandırılmış doğal bileşiklerdir. Aktif ambalajlama ajanı olarak kullanımlarında esansiyel yağın kimyasal bileşimi, polimer ile etkileşimi, karışım oranı gibi çeşitli özellikler dikkate alınarak, mekanik, kimyasal ve optik özellikleri ayarlanabilir ambalaj malzemeleri elde edilebilmektedir. Aynı zamanda mikrokapsülleme gibi yenilikçi yaklaşımlarla da, istenmeyen organoleptik özelliklerin önüne geçilmesine olanak sağlayan yavaş salımlı, dozunda kullanımları başarılmıştır.

Çeşitli gıda ürünleri arasında son yıllarda peynir türlerinin esansiyel bileşenlerle aktif ambalajlandığı başarılı çalışmalar görülmeye başlanmıştır. $\mathrm{Bu}$ konuda uygulanmalarını kısıtlayabilecek en önemli problem, esansiyel yağların sahip oldukları güçlü aromadır. Bu durum özellikle yağlı süt ürünlerinde, esansiyel bileşenlerin kimyasal özellikleri nedeniyle daha güçlü organoleptik kusurlara sebep olabilir. Bunun dışında bir diğer konu, aynı tür bitkiye ait esansiyel bileşimlerin çok çeşitli faktöre bağlı olarak değişiklik gösterebilmesi nedeniyle bir standardının olmayışıdır. Bu durum sadece süt ürünlerinde değil, genel anlamda pratik uygulamalarını kısıtlayabilir. Ayrıca çok sayıda bileşiği bir arada bulunduran esansiyel yağların, alerji problemleri oluşturabileceği de akılda tutulmalıdır.

Tüm olumlu ve riskli yönleri göz önüne alındığında, esansiyel yağlar, sınırsız bitki çeşitliliğiyle doğanın ürettiği ve sentetik koruyuculara kıyasla değerlendirilmesi gereken faydaları kaydedilmiş olan bileşiklerdir. Süt ürünlerinin aktif ambalajlanmasında gelecek vadeden, geliştirilmeye açık bir alan olduğu düşünülmektedir.

\section{KAYNAKLAR}

Abdollahi M, Rezaei M, Farzi G (2012) Improvement of active chitosan film properties with rosemary essential oil for food packaging. International Journal of Food Science \& Technology 47(4): 847-853. doi:10.1111/j.1365-2621.2011.02917.x

Ahmed J, Hiremath N, Jacob H (2016) Antimicrobial efficacies of essential oils/nanoparticles incorporated polylactide films against L. monocytogenes and $\mathrm{S}$. typhimurium on contaminated cheese. International Journal of Food Properties 20(1): 53-67. doi:10.1080/10942912.2015.1131165

Al-Asmari AK, Athar MT, Al-Faraidy AA, Almuhaiza MS (2017) Chemical composition of essential oil of
Thymus vulgaris collected from Saudi Arabian market. Asian Pacific Journal of Tropical Biomedicine 7(2): 147-150. doi:10.1016/j.apjtb.2016.11.023

Anonim $2016 \quad$ (Elektronik kaynak https://www.accessdata.fda.gov/scripts/cdrh/cfdocs/ cfcfr/CFRSearch.cfm?fr=182.20)

(Erişim Tarihi:10/02/2020)

Atarés L, Chiralt A (2016) Essential oils as additives in biodegradable films and coatings for active food packaging. Trends in Food Science \& Technology 48: 51-62. doi:10.1016/j.tifs.2015.12.001

Cheng M, Wang J, Zhang R, Kong R, Lu W, Wang X (2019) Characterization and application of the microencapsulated carvacrol/sodium alginate films as food packaging materials. International Journal of Biological Macromolecules 141: 259-267. doi:10.1016/j.ijbiomac.2019.08.215

Comer DK, Berry MF, Monfredi AJ, Lew CW (1995) Patent WO 9517816

Dannenberg GS, Funck GD, Cruxen CES, Marques JL, Silva WP, Fiorentini ÂM (2017) Essential oil from pink pepper as an antimicrobial component in cellulose acetate film: Potential for application as active packaging for sliced cheese. LWT - Food Science and Technology 81: 314-318. doi:10.1016/j.Iwt.2017.04.002

Desam NR, Al-Rajab AJ, Sharma M, Mylabathula MM, Gowkanapalli RR, Albratty M (2017) Chemical constituents, in vitro antibacterial and antifungal activity of Mentha $\times$ Piperita L. (peppermint) essential oils. Journal of King Saud University - Science doi:10.1016/j.jksus.2017.07.013

Dey A, Neogi S (2019) Oxygen scavengers for food packaging applications: A Review. Trends in Food Science \& Technology 90: 26-34. doi:10.1016/j.tifs.2019.05.013

Dobrucka R, Cierpiszewski R (2014) Active And Intelligent Packaging Food - Research And Development - A Review. Polish Journal of Food and Nutrition Sciences 64(1): 7-15. doi:10.2478/v10222-012-0091-3

Dorman HJD, Deans SG (2000) Antimicrobial agents from plants: antibacterial activity of plant volatile oils. Journal of Applied Microbiology 88 (2), 308-316. DOI: 10,1046 / j.1365-2672.2000.00969.x

Fisher K, Phillips C (2008) Potential antimicrobial uses of essential oils in food: is citrus the answer? Trends in Food Science \& Technology 19(3): 156-164. doi:10.1016/j.tifs.2007.11.006

Froiio F, Ginot L, Paolino D, Lebaz N, Bentaher A, Fessi H, Elaissari A (2019) Essential Oils-Loaded Polymer Particles: Preparation, Characterization and Ghadetaj A, Almasi H, Mehryar L (2018) Development and characterization of whey protein isolate active films containing nanoemulsions of Grammosciadium Antimicrobial Property. Polymers 11(6): 1017. doi:10.3390/polym11061017

Ghadetaj A, Almasi H, Mehryar L (2018) Development and characterization of whey protein isolate active films containing nanoemulsions of Grammosciadium 
ptrocarpum Bioss. essential oil. Food Packaging and Shelf Life 16: 31-40. doi:10.1016/j.fpsl.2018.01.012

Ghorbani A, Esmaeilizadeh M (2017) Pharmacological properties of Salvia officinalis and its components. Journal of Traditional and Complementary Medicine 7(4): 433-440. doi:10.1016/j.jtcme.2016.12.014

Gurdian C, Chouljenko A, Solval KM, Boeneke C, King JM, Sathivel S (2017) Application of Edible Films Containing Oregano (Origanum vulgare ) Essential Oil on Queso Blanco Cheese Prepared with Flaxseed (Linum usitatissimum ) Oil. Journal of Food Science 82(6): 1395-1401. doi:10.1111/1750-3841.13733

Hamidpour R, Hamidpour M, Hamidpour S, Shahlari M (2015) Cinnamon from the selection of traditional applications to its novel effects on the inhibition of angiogenesis in cancer cells and prevention of Alzheimer's disease, and a series of functions such as antioxidant, anticholesterol, antidiabetes, antibacterial, antifungal, nematicidal, acaracidal, and repellent activities. Journal of Traditional and Complementary Medicine 5(2): 66-70. doi:10.1016/j.jtcme.2014.11.008

Huang T, Qian Y, Wei J, Zhou C. (2019) Polymeric Antimicrobial Food Packaging and Its Applications. Polymers 11(3): 560. doi:10.3390/polym11030560

Jin TZ, Guo M, Chen W (2018) Packaging Methods To Effectively Deliver Natural Antimicrobials on Food. In: Fan X, Ngo H, Wu C (eds.), Natural and Bio-Based Antimicrobials for Food Applications, ACS Symposium Series, American Chemical Society, Washington, DC, 171-192.

Ju J, Chen X, Xie Y, Yu H, Guo Y, Cheng Y, ... Yao W (2019) Application of essential oil as a sustained release preparation in food packaging. Trends in Food Science \& $\quad$ Technology 22-32. doi:10.1016/j.tifs.2019.08.005

Katar N, Katar D, Aydın D, Olgun M (2018) Tıbbi Adaçayı (Salvia officinalis L.)'nda Uçucu Yağ Oranı ve Kompozisyonu Üzerine Ontogenetik Varyabilitenin Etkisi. Uluslararası Tarım ve Yaban Hayatı Bilimleri Dergisi 4(2): $231-236$

Kılıç S (2010) Süt Mikrobiyolojisi. Sidas Media, İzmir.

Kim H, Beak SE, Yang SY, Song KB (2017) Application of an antimicrobial packaging material from chicken bone gelatine and cinnamon bark oil to mozzarella cheese. International Journal of Food Science \& Technology 53(3): 619-625. doi:10.1111/ijfs.13636

Ksouda G, Sellimi S, Merlier F, Falcimaigne-cordin A, Thomasset B, Nasri M, Hajji M (2019) Composition, antibacterial and antioxidant activities of Pimpinella saxifraga essential oil and application to cheese preservation as coating additive. Food Chemistry 288: 47-56. doi:10.1016/j.foodchem.2019.02.103

Kuorwel KK, Cran MJ, Sonneveld K, Miltz J, Bigger SW. (2013) Physico-Mechanical Properties of Starch-Based Films Containing Naturally Derived Antimicrobial
Agents. Packaging Technology and Science 27(2): 149-159. doi:10.1002/pts.2015

Küçük S, Çetintaş $E$, Kürkçüoğlu M, (2018) Volatile compounds of the Lavandula angustifolia Mill. (Lamiaceae) Species Cultured in Turkey. M. JOTCSA 5(3): 1303-1308. https://doi.org/10.18596/jotcsa.463689

Lin L, Liao X, Cui H (2019) Cold plasma treated thyme essential oil/silk fibroin nanofibers against Salmonella Typhimurium in poultry meat. Food Packaging and Shelf Life 21: 100337. doi:10.1016/j.fpsl.2019.100337

Mahboubi M (2018) Caraway as Important Medicinal Plants in Management of Diseases. Natural Products and Bioprospecting 9: 1-11doi:10.1007/s13659-018-0190$\mathrm{x}$

Metin M (2012) Süt Teknolojisi Sütün Bileşimi ve İşlenmesi. Ege Üniversitesi Basımevi, İzmir. ISBN-10:9754832792

Minagawa F (1997) Patent JP 09169401

Nakahara M, Nakahara T, Sasaki Y, Kai S (1995) Patent JP 07207165

O' Callaghan KAM, Kerry JP (2014) Assessment of the antimicrobial activity of potentially active substances (nanoparticled and non-nanoparticled) against cheese-derived micro-organisms. International Journal of Dairy Technology 67(4): 483-489. doi:10.1111/1471-0307.12160

Otero V, Becerril R, Santos JA, Rodríguez-Calleja JM, Nerín C, García-López ML (2014) Evaluation of two antimicrobial packaging films against Escherichia coli 0157:H7 strains in vitro and during storage of a Spanish ripened sheep cheese (Zamorano). Food Control 42: 296-302. doi:10.1016/j.foodcont.2014.02.022

Pandey AK, Singh P, Tripathi NN (2014) Chemistry and bioactivities of essential oils of some Ocimum species: an overview. Asian Pacific Journal of Tropical Biomedicine, 4(9): 682-694. doi:10.12980/apjtb.4.2014c77

Rather MA, Dar BA, Sofi SN, Bhat BA, Qurishi M A (2016) Foeniculum vulgare: $A$ comprehensive review of its traditional use, phytochemistry, pharmacology, and safety. Arabian Journal of Chemistry 9: 1574-1583. doi:10.1016/j.arabjc.2012.04.011

Ribeiro-Santos R, Andrade M, Melo NR, Sanches-Silva A (2017) Use of essential oils in active food packaging: Recent advances and future trends. Trends in Food Science \& Technology 61: 132-140. doi:10.1016/j.tifs.2016.11.021

Suzuki Y, Yagishita Y (1997) Patent JP 09235490

Takayama C, Faria FM, Almeida ACA, Dunder RJ, Manzo LP, Socca EAR, ... Luiz-Ferreira A (2016) Chemical composition of Rosmarinus officinalis essential oil and antioxidant action against gastric damage induced by absolute ethanol in the rat. Asian Pacific Journal of Tropical Biomedicine 6(8): 677-681. doi:10.1016/j.apjtb.2015.09.027 
Talón E, Vargas M, Chiralt A, González-Martínez C (2019) Eugenol incorporation into thermoprocessed starch films using different encapsulating materials. Food Packaging and Shelf Life 21: 100326. doi:10.1016/j.fpsl.2019.100326

Tatlisu NB, Yilmaz MT, Arici M (2019) Fabrication and characterization of thymol-loaded nanofiber mats as a novel antimould surface material for coating cheese surface. Food Packaging and Shelf Life 21: 100347. doi:10.1016/j.fpsl.2019.100347

Tchatchouang S, Beng VP, Kuete V (2017) Antiemetic African Medicinal Spices and Vegetables. In: Kuete V (ed) Medicinal Spices and Vegetables from Africa, Academic Press, Dschang, Kamerun, 299-313. doi:10.1016/b978-0-12-809286-6.00011-x

Tiwarı BK, Valdramıdıs VP, O' Donnell CP, Muthukumarappan K, Bourke P, Cullen PJ (2009) Application of Natural Antimicrobials for Food Preservation. J. Agric. Food Chem. 57; 5987-6000. DOI:10.1021/jf900668n

Tohidi B, Rahimmalek M, Trindade H (2019) Review on essential oil, extracts composition, molecular and phytochemical properties of Thymus species in Iran. Industrial Crops and Products 134: 89-99. doi:10.1016/j.indcrop.2019.02.038

Tyagi AK, Malik A (2011) Antimicrobial potential and chemical composition of Mentha piperita oil in liquid and vapour phase against food spoiling microorganisms. Food Control 22(11): 1707-1714. doi:10.1016/j.foodcont.2011.04.002

Vilela C, Kurek M, Hayouka Z, Röcker B, Yildirim S, Antunes MDC, ... Freire CSR. (2018) A concise guide to active
ERTEKIN B

agents for active food packaging. Trends in Food Science \& Technology 80: 212-222. doi:10.1016/j.tifs.2018.08.006

Vilela J, Martins D, Monteiro-Silva F, González-Aguilar G, Almeida JMMM, Saraiva C (2016) Antimicrobial effect of essential oils of Laurus nobilis $L$. and Rosmarinus officinallis L. on shelf-life of minced "Maronesa" beef stored under different packaging conditions. Food Packaging and Shelf Life 8: 71-80. doi:10.1016/j.fpsl.2016.04.002

Viuda-Martos M, Ruiz-Navajas Y, Fernandez-Lopez J, Perez A, Ivarez J (2008) Antıbacterial activity of lemon (citrus lemon I.), mandarın (cıtrus retıculata I.), grapefruit (cıtrus paradisı I.) and orange (citrus sınensis I.) essential oıls. Journal of Food Safety 28(4): 567-576. doi:10.1111/j.1745-4565.2008.00131.x

Wen P, Zhu DH, Feng K, Liu FJ, Lou WY, Li N, ... Wu H (2016) Fabrication of electrospun polylactic acid nanofilm incorporating cinnamon essential oil/ $\beta$-cyclodextrin inclusion complex for antimicrobial packaging. Food Chemistry 196: 996-1004. doi:10.1016/j.foodchem.2015.10.043

Wynn SG, Fougère B J (2007) Materia Medica. In: Wynn SG, Fougère, BJ (eds.) Veterinary Herbal Medicine, Sydney, Australia, 459-672 doi:10.1016/b978-0-32302998-8.50028-7

Yang SY, Cao L, Kim H, Beak SE, Song KB (2017) Utilization of Foxtail Millet Starch Film Incorporated with Clove Leaf Oil for the Packaging of Queso Blanco Cheese as a Model Food. Starch - Stärke 70(3-4): 1700171. doi:10.1002/star.201700171 
